\title{
Nature of Aggregation in Two Tropical Soils of Puerto Rico
}

\author{
Raul Pérez Escolar and M. A. Lugo López
}

\section{INTRODUCTION}

Papers concerning the nature and properties of tropical soil aggregates are generally characterized by mere speculations and observations, rather than by facts and data. It is frequently stated that the great stability of some tropical soil aggregates is entirely due to the presence of free iron and aluminum sesquioxides. No direct measurements of the effect of these cementing agents have been made really to evaluate their influence. In the light of the zonality principle which stresses the constancy of organic matter in the different parts of the world, no role is given to this cementing agent as a stabilizer of aggregates in tropical areas. This paper deals with the nature and possible formation of aggregates in some tropical soils. This investigation was initiated because of the lack of information concerning soil aggregation in tropical areas.

\section{MATERIALS AND METHODS}

Samples of the surface soil of Catalina clay and Cialitos clay were taken in the Central Mountainous Rainy Region of Puerto Rico. Both are deep, acid soils with low inherent fertility. Catalina is a Tropectic, clayey, oxidic, isohyperthermic Oxisol. ${ }^{2}$ Cialitos is an Orthoxic, clayey, oxidic, isohyperthermic Ultisol. ${ }^{3}$ The samples studied in this work were taken from pastures where grasses and weeds constituted the predominant vegetation.

In order to determine the aggregate distribution, the soils were dryscreened by shaking for 3 minutes in a Tyler automatic Ro-tap machine which has a circular horizontal motion.

The method proposed by Bryant, Bendixen, and Slater (1) 4 was used in the separation of water-stable aggregates. This method was modified by leaving the aggregates immersed in water for 16 hours followed by wet

1 Associate Soil Scientist and Soil Scientist, respectively, Agricultural Experiment Station, Mayagüez Campus, University of Puerto Rico, Río Piedras, P.R.

2 Order including soils with a horizon whose total exchange capacity is less than $16 \mathrm{meq} . / 100 \mathrm{gm}$. where cations are less than $12 \mathrm{meq}$. The soils included in this order do not exhibit clayfilms and the structure is either very weak or nonexistent.

3 Order including soils with an argillic horizon with less than 35 -percent base saturation, decreasing with depth. It has clayskins and a well-developed structure with a cation exchange capacity ranging between 16 and 24 meq. $/ 100 \mathrm{gm}$. of dry soil.

- Numbers in parentheses refer to Literature Cited, p. 232. 
screening for 15 minutes. The reason for soaking them so long was to insure a thorough uniform wetting.

The pipette method as modified by Kilmer and Alexander ( 3 ) was used to determine particle-size distribution. Because of the long-used theory that organic matter in Ultisols and Oxisols is very low, no hydrogen peroxide treatment was included in the analyses at the beginning. Results will be shown later which make clear the necessity of including this oxidizing agent prior to the determination of particle-size distribution in these soils, if accurate results are desired.

Originally it had been intended to use the soil on which free iron oxides had been determined for particle-size distribution. The reason was that

TABLE 1. The effect of $\mathrm{H}_{2} \mathrm{O}_{2}$ on particle-size distribution of Catalina clay

\begin{tabular}{c|c|c|c}
\hline \multirow{2}{*}{$\begin{array}{c}\text { Aggregate size } \\
\text { (millimeters) }\end{array}$} & Soil separate & \multicolumn{2}{|c}{ Content of indicated separate when- } \\
\cline { 2 - 3 } & & Treated with $\mathrm{H}_{2} \mathrm{O}_{2}$ & Untreated \\
\hline \multirow{3}{*}{$5-3$} & & Percent & Percent \\
& Sand & 12.3 & 31.3 \\
& Silt & 26.8 & 36.4 \\
Clay & 60.0 & 33.8 \\
& & & \\
& Sand & 12.1 & 21.4 \\
& Silt & 23.9 & 45.3 \\
& Clay & 61.7 & 32.3 \\
& Sand & 14.5 & 23.2 \\
& Silt & 23.9 & 43.8 \\
& Clay & 61.0 & 33.7 \\
\hline
\end{tabular}

iron and aluminum, because of their flocculating ability, might interfere with a complete dispersion. It was found, however, that stable suspensions were obtained without this treatment, thus saving considerable time.

The chromic acid reduction method proposed by Walkley and Black (4) was used in determining organic matter.

The method proposed by Jeffries (2), namely, the potassium oxalateoxalic acid-magnesium ribbon procedure, was used for determining free iron oxides.

\section{RESULTS AND DISCUSSION}

Table 1 shows the effect of excluding hydrogen peroxide prior to mechanical analysis. The importance of organic matter as a cementing agent in these aggregates is demonstrated by the fact that, when the particle-dis- 
tribution determinations were made without the use of hydrogen peroxide, the values obtained for clay were extremely low.

Table 2 shows that there is very little variation in organic-matter content, particle-size distribution, and free iron oxides among the differentsized aggregates, and the whole soils from which they were separated. There are no outstanding differences in organic-matter content of the differentsized aggregates of either Cialitos clay or Catalina clay. The 2 to $1-\mathrm{mm}$. aggregates of Cialitos clay appear to contain a slightly higher amount, yet they are less water-stable than the 5 to $3-\mathrm{mm}$. aggregates. The 2 to $1-\mathrm{mm}$. aggregates of Catalina clay contain the smallest amount of organic matter of the aggregate groups tested.

It is interesting to note that the fine and very fine sand content of all the aggregates and the corresponding whole soils is practically the same. The greatest degree of similarity is found between the whole soil and the aggregates larger than $5 \mathrm{~mm}$. in both Catalina and Cialitos. In this aggregate fraction, virtually every sand fraction is about the same as the corresponding total soils. This condition was found in both soils studied.

The content of free oxides of the aggregates and of the whole soil in Cialitos clay is practically the same. In Catalina, however, the 2 to $1-\mathrm{mm}$. aggregates show a slight increase in oxides. Still they are less water-stable than the larger aggregates.

The only marked difference in the properties of the aggregates of the two soils is their water stability. It appears likely that the differences are significant at least when eight replicates were used for this determination. The results in each size-aggregate studied were very consistent. The difference between the stability of the 3 to 2- and 2 to $1-\mathrm{mm}$. aggregates of Catalina clay was greater than between those of Cialitos clay. It is surprising that even though the 2 to $1-\mathrm{mm}$. aggregates contained slightly more free oxides, they are less water-stable than the larger aggregates. These same-sized aggregates in Cialtios clay exhibit less stability, even though their organic-matter content is slightly higher than that of other aggregates.

The fact that the larger aggregates might occur in the soil surface, or close to it, could account in part for these differences. They are thus exposed to more drastic dehydration which results in a more pronounced irreversibility of the cementing agents, thus exhibiting more stability against the slaking forces of water.

Although it is difficult to theorize on the formation of aggregates in these soils, some comment may be justified. Apparently aggregates are formed to a great extent by disintegration of large massive units of soils. How were the large units formed if it were not by synthesis? There is no 
TABLE 2-Particle-size distribution, organic-matter content, free-iron oxide content, aggregale distribulion, and water stable aggregates in Catalina and Cialitos soils

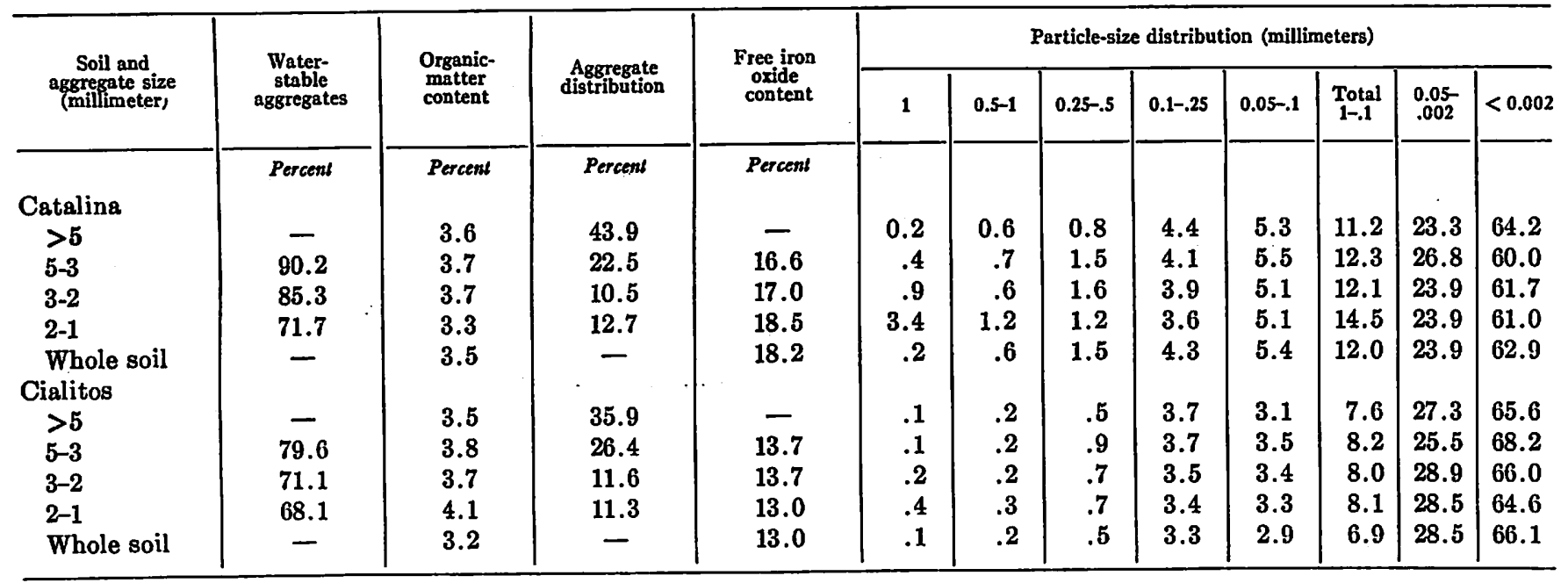


doubt that this process has operated to some extent. However, other processes are also operative. Apparently, big massive units appeared in the process of soil formation and disintegration of these large units occurred due to the development of cohesive forces during drying periods. The structure developed attained a degree of stability from precipitation of iron and aluminum brought to the outer surface of the aggregates by capillary movement with moisture within the aggregate. Organic matter probably also played a role in this stabilization process. Redispersion might have occurred and actually does occur, but because of the irreversible character of sesquioxides, and the fact that, as the soil-formation process goes on, more sesquioxides appear, the aggregates formed exhibit a particular stability as shown in the soils studied. If synthesis occurred to a greater extent in the formation of the aggregates studied it would seem logical to find more differences in the constitutional makeup of the different-sized aggregates. One point which seems to support the postulated comment is that, in the sand fraction of the soils studied, the fine and very fine sand are rather constant in the aggregates of various sizes studied. The aggregates larger than $5 \mathrm{~mm}$., that make up the bulk of aggregates in both soils, appear to be the most similar to the whole soil in every respect.

The organic-matter content, although similar in the two soils, cannot be used as a basis for comparison. The place and time at which the samples were taken may vary and thus produce results that might not hold under equilibrium conditions.

The aggregates in Catalina appear to exhibit a higher degree of water stability than Cialitos. The reason appears quite obvious if we consider that Catalina clay has a higher percentage of free iron oxides. This difference in oxides between the two soil types studied might indicate a more advanced stage of soil formation in Catalina than in Cialitos clay.

\section{SUMMARY}

In both Catalina clay and Cialitos clay there are no marked differences in the properties of the different-sized aggregates and the corresponding whole soils studied. Although well-drained upland soils in the Tropics are supposed to contain less organic matter than those in the cooler Temperate Zones, the organic-matter content of Catalina clay and Cialitos clay was as great as that found in many soils of the same texture in Temperate Zones. Organic matter has a very definite influence as a cementing agent between clay particles. This was shown by the low clay values obtained when organic matter was not removed by pretreating the soil with hydrogen peroxide prior to mechanical analysis.

From the general data obtained in the study of the aggregates of both soils, it can be inferred that they are formed largely as a result of the 
breakdown of large massive units of soils. If synthesis occurred to a larger extent, more marked differences could be expected in their constitutional makeup.

\section{RESUMEN}

No se encontraron diferencias apreciables entre las propiedades de los agregados de diversos tamaños y las de los suelos completos (mezcla natural de todos los agregados) de los tipos Catalina arcilloso y Cialitos arcilloso. Aunque se supone que los suelos de altura de los Trópicos con un buen desagüe contienen menos materia orgánica que otros similares en las zonas más frías y templadas, en este estudio se encontró que el contenido de materia orgánica en los tipos Catalina y Cialitos era tan alto como el de muchos suelos de igual textura en las Zonas Templadas. La materia orgánica influye definitivamente como agente cementoso entre las partículas arcillosas. Esto lo comprobaron los valores bajos de la arcilla obtenidos cuando las muestras no se trataron con agua oxigenada para eliminar la materia orgánica antes de hacer el análisis mecánico.

De los datos obtenidos en este estudio de los agregados de ambos suelos, puede inferirse que éstos se forman mayormente como resultado de la desintegración de mayores unidades masivas. Si ocurriera un mayor grado de síntesis, podrían esperarse mayores diferencias en la constitución de los agregados.

\section{LITERATURE CITED}

1. Bryant, J. C., Bendixen, T. W., and Slater, C. S., Measurements of the water stability of soils, Soil Sci. 65: 341-5, 1948.

2. Jeffries, C. D., A rapid method for the removal of free iron oxides prior to petrographic analysis, Soil Sci. Soc. Amer. Proc. 11: 211-12, 1946.

3. Kilmer, V. J., and Alexander, J. T., Methods of making mechanical analyses of soils, Soil Sci. 68: 15-24, 1949.

4. Walkley, A., and Black, T. A., An examination of the Degtjareff method for determining soil organic matter and a proposed modification of the chromic acid titration method, Soil Sci. 37: 29-38, 1934. 